\title{
Implementasi Framework Codeigniter Pada Perancangan Chatbot Interaktif Menerapkan Metode Waterfall
}

\author{
Nilam Cahya, Agung Triayudi*, Benrahman \\ Sistem Informasi, Fakultas Teknologi Komunikasi dan Informatika, Universitas Nasional, Jakarta, Indonesia \\ Email: 1nilamchyaa99@gmail.com, 2,*agungtriayudi@civitas.unas.ac.id, ${ }^{3}$ ben.rahman@ gmail.com \\ Email Penulis Korespondens: Agung Triayudi
}

\begin{abstract}
Abstrak-Dalam rangka mendukung kebutuhan informasi terkait perkuliahan, website Sistem Informasi Universitas Nasional sudah menyediakan fitur RoomChat untuk sesi tanya jawab antara admin dengan user, namun banyaknya pesan yang masuk menjadikan fitur tersebut masih kurang efektif karena berdampak pada tenggang waktu untuk admin bisa merespon pertanyaan user. Dalam penelitian ini, penulis ingin merancang fitur Chatbot Interaktif dimana user bisa berinteraksi dengan chatbot yang tehubung ke database. Database chatbot ini menyediakan kata kunci serta kunci jawaban yang diatur oleh admin, sehingga dalam pengimplementasiannya admin bisa menambah atau mengupdate kosa kata untuk chatbot. Pemanfaatan metode waterfall dibagi menjadi 5 tahapan, yaitu analysis, design, implementasi, testing hingga proses maintenance. Sementara dalam pengerjaan aplikasi, chatbot ini dibuat menggunakan framework Codeigniter yang menyediakan MVC yang baik dalam pengkodeannya. Hasil akhir dari penelitian ini adalah Fitur chatbot yang terintegrasi dengan database admin chatbot sehingga informasi yang diterima user selalu update dengan perkembangan perkuliahan di program studi Sistem Informasi.
\end{abstract}

Kata Kunci: Chatbot; Framework Codeignite; Metode Waterfall.

\begin{abstract}
In delivering information related to lecture activities at the National University, the Information Systems Study Program has prepared a special website, namely http://si.ftki.unas.ac.id/. The website contains a lot of information about important activities or announcements, it's just that the need for other supporting information makes users have the need to ask further questions regarding the information contained on the website. Actually the Website http://si.ftki.unas.ac.id/ has provided the RoomChat feature for question and answer sessions between admin and users, but this feature is still ineffective, such as there is a time lag between questions and responses or unable to provide services for $24 \mathrm{jam}$. In this study, the authors wanted to design the chatbot feature using the waterfall method, which was carried out sequentially starting from the planning, analysis, design, implementation, testing to maintenance stages. While working on the application, this chatbot was created using the Codeigniter framework with the mysqli database. This chatbot feature will result in a more interactive question and answer session, so that two-way communication with users can run smoothly.
\end{abstract}

Keywords: Chatbot; Codeigniter Framework; Waterfall Method

\section{PENDAHULUAN}

Website menjadi salah satu media informasi yang berperan penting dalam pengelolaan informasi, tidak terkecuali dalam lingkungan Universitas Nasional. Dalam hal ini, Program Studi Sistem Informasi telah memiliki website sendiri yaitu http://si.ftki.unas.ac.id/, website tersebut digunakan_untuk mengelola informasi terkait segala kegiatan atau pengumuman penting lainnya terkait kebutuhan mahasiswa Prodi Sistem Informasi.

Selain itu, untuk menunjang kebutuhan user dalam bertanya terkait informasi lebih lanjut yang tertera di dalam website, website Prodi Sistem Informasi telah menyediakan fitur RoomChat sebagai tempat sesi tanya jawab antara admin dengan user. Fitur RoomChat ini sebenarnya telah berfungsi dengan baik, namun pada kondisi tertentu membuat fungsi fitur ini menjadi kurang interaktif. Hal ini dikarenakan fitur tersebut masih menggunakan admin sebagai responden, yang mengakibatkan adanya jeda waktu yang cukup lama antara pertanyaan dan tanggapan serta tidak dapat menyediakan pelayanan selama 24 jam.

Perancangan chatbot ini tidak terlepas dari berbagai penelitian terdahulu terkait chatbot dalam berbagai bidang. Seperti dalam penelitian [1]"Rancang Bangun Chatbot Untuk Meningkatkan Performa Bisnis." Penelitian ini bertujuan merancang sistem yang mampu membantu menangani ribuan pesan yang masuk lewat berbagai saluran komunikasi. Kemudian dalam bidang kesehatan, penelitian tentang chatbot pun pernah dipublikasian dalam judul [2] "Pembangunan Aplikasi Chatbot Midwify sebagai Media Pendukung Pembelajaran Ilmu Kebidanan Berbasis Android di Stikes Bhakti Kencana Bandung.”. Selanjutnya, dalam penelitian lain yang berjudul [3] "Aplikasi Chatbot (Milki Bot) Yang Terintegrasi Dengan Web Cms Untuk Customer Service Pada Ukm Minsu." Dalam penelitian ini Sistem ini dapat menggantikan peran manusia sebagai tugas customer service, salah satunya adalah melayani pelanggan untuk melakukan tanya jawab dan juga dapat melakukan pemesanan. Dan yang tak kalah menarik juga, penelitian terkait [4] "Rancang Bangun Chatbot Pembelajaran Java Pada Google Classroom Dan Facebook Messenger." Yang didasari kurangnya interaksi dimana user hanya diberikan beberapa pilihan untuk menjawab pertanyaan. Dengan keterbatasan interaksi tersebut penulis tertarik untuk membangun aplikasi chatbot dimana user dapat melakukan tanya jawab dengan sistem untuk mendapatkan informasi yang diinginkan.

Oleh karena itu, dalam penelitian ini penulis ingin merancang fitur Chatbot pada website Prodi Sistem Informasi (SIBot) dengan menggunakan Framework Codeigniter serta database Mysqli sebagai tempat penyimpanan data. Penerapan fitur Chatbot pada website Prodi Sistem Informasi dapat mengurangi tugas dari 
admin customer service, sehingga dapat menghemat biaya operasional. Fitur ini juga dapat menjawab pertanyaan dari banyak user dalam waktu yang bersamaan, serta memastikan semua pesan dari user dapat ditangani dengan cepat. Dengan adanya fitur ini akan menghasilkan sesi tanya jawab yang lebih interaktif dengan kata kunci dan bahasa yang dapat di update oleh admin, sehingga memperkaya kosa kata untuk chatbot dan menjadikan komunikasi dua arah antara chatbot dengan user dapat berjalan dengan efektif dan efisien.

\section{METODOLOGI PENELITIAN}

\subsection{Metode Waterfall (SDLC)}

Penelitian terkait dengan fitur Chatbot Prodi Sistem Informasi (SIBot) ini menggunakan metode Waterfall (SDLC). Dimana SDLC ini menjadi kerangka yang berisi tahapan yang perlu dilakukan untuk mengembangkan suatu perangkat lunak.

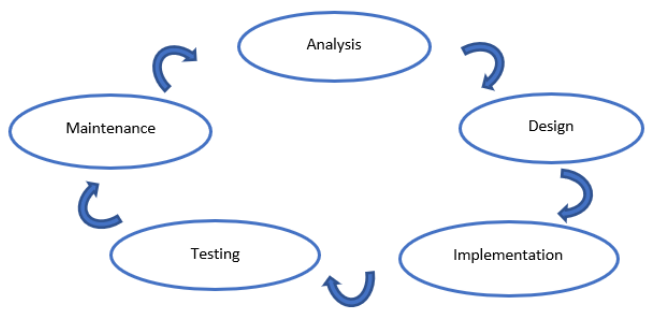

Gambar 2. Tahapan Metode SDLC

Adapun tahapan yang terdapat dalam metode SDLC ini adalah:

\section{Analysis}

Pada tahap ini peneliti menganalisis struktur dan alur sistem pada sistem yang sedang berjalan di website Program Studi Sistem Informasi Universitas Nasional. Metode pengumpulan data pada perancangan chatbot ini menerapkan tiga cara:

a. Studi pustaka dengan mengumpulkan studi kasus yang relevan terkait infromasi yang serupa.

b. Observasi langsung pada website terkait yaitu website sistem informasi Universitas Nasional

c. Wawancara dengan mahasiswa dari program studi sistem informasi terkait apa saja yang diperlukan dalam proses perancangan chatbot.

Setelah data yang diperlukan terkumpul, Selanjutnya adalah mengolah seluruh informasi yang didapat untuk keperluan analisa sistem yang akan dibangun. Setelah menemukan analisa yang sesuai dengan system yang berjalan saat ini, selanjutnya adalah mengamati ruang lingkup terkait penerapan fitur chatbot. Pada tahapan ini ditentukan cakupan (scope) dari chatbot yang akan dibuat[5][6]. Dalam hal ini, batasan yang peneliti buat terhadap fitur chatbot yang akan dibuat adalah hanya mencakup kegiatan internal (pembelajaran di lingkungan perkuliahan) dan eksternal(organisasi dan informasi akademik) di lingkungan program studi sistem informasi. Selain itu segala perancangan terkait alur kerja chatbot dilakukan pada tahapan ini.

\section{Design}

Desain merupakan tahapan dalam membuat alur atau proses dan tampilan fitur pada sistem yang akan dibuat berdasarkan pengamatan dari tahapan analysis yang sudah dilakukan pada tahapan sebelumnya. Pada tahap ini, dilakukan rancangan terkait pemodelan chatbot baik untuk user maupun untuk admin selaku customer service dalam chatbot dibuat. Dari tahapan ini, diperoleh rancangan interface yang akan di jadikan acuan untuk melakukan pengkodean di sisi aplikasi[7][8].

\section{Implementasi}

Implementasi merupakan tahapan penulisan kode program untuk membuat desain tampilan antar muka dan proses kerja chatbot berdasarkan tahapan desain yang sudah dibuat[9]. Pada tahapan pengimplementasian sistem, pengkodean dilakukan dengan menggunakan Framework Codeigniter sebagai base penulisan program. Sementara database msyqli digunakan untuk menampung seluruh informasi yang terangkum dalam chatbot. Tahap ini dibagi menjadi beberapa proses:

1) Design Review, yaitu memeriksa setiap elemen HTML yang digunakan, memperhatikan penggunaan font dalam setiap tulisan, dan memperhatikan fungsionalitas framework yang digunakan pada pengembangan website.

2) Pemilihan sumber daya hardware dan software, proses ini berhubungan dengan teknologi yang akan digunakan dalan penulisan kode program dan instalasinya. Dan tentunya pemilihan ini didasarkan pada rung lingkup serta sumber daya pendukung lainnya.

\section{Testing}


Pengujian Fitur, yaitu melakukan pengujian sistem untuk menguji kinerja dari fitur yang telah selesai dibuat dan mencari kekurangan dari fitur yang baru selesai diimplementasikan. Pada tahap ini, chatbot yang telah selesai dibuat akan diuji dari segi fungsionalitas chatbot. Tahapan ini akan menentukan proses apa yang akan dilakukan selanjutnya oleh sistem. Jika terdapat kesalahan pada sistem pada saat proses uji coba maka proses selanjutnya akan dikembalikan pada tahap sebelumnya yaitu tahapan impementasian sistem untuk dilakuan evaluasi terhadap proses yang masih gagal. Sebaliknya jika pada tahap pengujian tidak ditemukan kesalahan pada sistem, maka fitur chatbot yang dirancang sudah dapat di terapkan di website program studi Sistem Informasi Universitas Nasional[10].

\section{Maintenance}

Setelah chatbot bisa dipastikan untuk dipubliskasikan di website sistem informasi, tahap selanjutnya adalah melakukan pemeliharaan terhadap sistem secara berkala. Tujuannya adalah untuk memastikan fitur dapat bekerja dengan baik dan selalu update dengan perkembangan zaman[11].

\subsection{Chatbot}

Chatbot adalah fitur yang memanfaatkan kecerdasan buatan sebagai bahasa alami yang dapat berkomunikasi dengan penggunanya. Setiap chatbot diatur oleh seorang botmaster, yaitu orang dibelakang layar yang berandil besar dalam membentuk suatu kepribadian bot serta pengetahuan chatbot. [12][13] Chatbot merupakan teknologi yang sering berkembang dalam penyempurnaan sistemnya. Chatbot sudah di implementasikan melalui jejaring sosial, seperti twitter dan Windows Live Messenger. Portal online populer seperti eBay dan PayPal juga menggunakan agen virtual multi bahasa untuk memudahkan penggunanya. Chatbot dapat dengan cepat menanggapi pertanyaan user, namun sebenarnya bot tersebut hanya mengartikan kata kunci yang di input dan memberikan tanggapan dengan kata kunci yang paling mirip dari dalam database yang telah dibuat sebelumnya.

\subsection{Framework Codeigniter}

CodeIgniter adalah sebuah framework PHP yang dapat membantu mempercepat developer dalam pengembangan aplikasi web berbasis PHP dibanding jika menulis semua kode program dari awal [14][15]. Framework Codeigniter dapat digunakan sebagai pemisah kode program antara View, Controller, dan Model. View bertugas mengatur tampilan, Controller sebagai pusat logika, dan Model bertujuan untuk mengatur data pada database.

\subsection{Black Box Testing}

Black Box Pengujian blackbox merupakan pengujian dimana kasus uji didesain berdasarkan spesifikasi dan berfokus pada output yang dihasilkan sebagai respon dari inputyang dipilih dan kondisi-kondisi eksekusi. [17] Dengan menggunakan black box testing, penguji hanya perlu mencari kesalahan program dengan menguji fungsionalitas system tanpa perlu mengetahui struktur pemrogramannya [16].

\section{HASIL DAN PEMBAHASAN}

\subsection{Konsep Aplikasi}

Aplikasi SIBot merupakan aplikasi berbasis chatbot yang membantu mahasiswa Prodi Sistem Informasi Universitas Nasional dalam mencari informasi yang dibutuhkan. Aplikasi ini hadir dalam bentuk fitur yang ada pada website Sistem Informasi sehingga mudah untuk digunakan dan dapat diakses secara langsung oleh mahasiswa. Konsep dalam penelitian SIBot ini dapat di dijelaskan dengan flowchart seperti berikut:

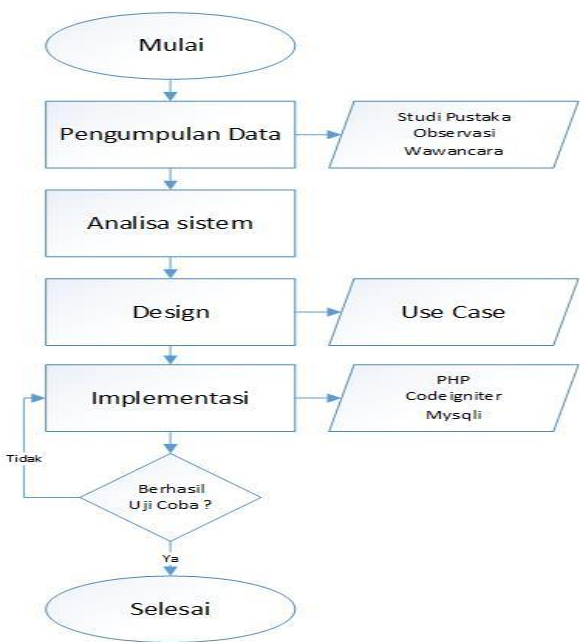

Gambar 1. Konsep Perancangan SIBot 
ISSN 2614-5278 (media cetak), ISSN 2548-8368 (media online)

Available Online at https://ejurnal.stmik-budidarma.ac.id/index.php/mib DOI 10.30865/mib.v5i1.2623

\subsection{Use Case Diagram}

Pada Use Case Diagram digambarkan aktivitas dari actor dalam penggunaan sistem berikut. Antara lain:

a. Admin

Sebelum melakukan aktivitas pada halaman admin, admin harus melakukan login terlebih dahulu kemudian setelah melakukan login aktivitas yang dapat di lakukan adalah sebagai berikut :

1. Menambah knowledge base

2. Mengubah knowledge base

3. Melihat riwayat chat

b. User

User dapat membuka fitur chatbot pada halaman website, aktivitas yang dapat di lakukan adalah sebagai berikut:

1. Mengajukan pertanyaan

2. Menerima respon chatbot

c. Chatbot System

Chatbot system ini terintegrasi dengan database sehingga dalam pengelolaan kosa kata pertanyaan dan jawaban dapat diatur oleh admin. Aktivitas yang dapat di lakukan adalah sebagai berikut:

1. Menerima pertanyaan dari user

2. Merespon pertanyaan user

3. Menyimpan riwayat chat kedalam database

4. Mengajukan pertanyaan yang tidak ada dalam database kepada admin

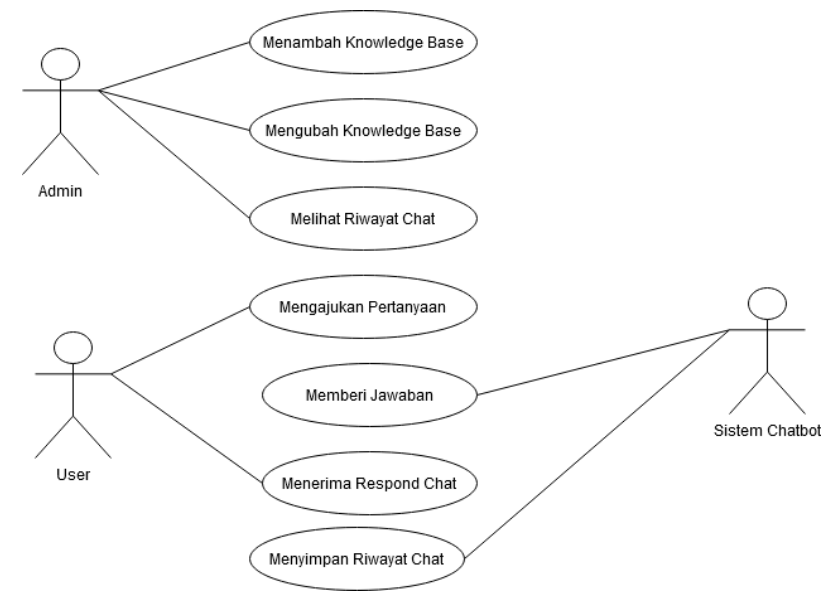

Gambar 3. Use Case Diagram SIBot

\subsection{Analisa Kebutuhan Chatbot}

Aplikasi Chatbot pada website Sistem Informasi dibangun menggunakan Framework Codeigniter. Hal ini bertujuan untuk membantu developer dalam membagi kode program menjadi 3 aktor. Adapun aktor yang dibutuhkan pada fitur chatbot website Sistem Informasi di gambarkan pada tabel 1.

Tabel 1. Identifikasi Aktor

\begin{tabular}{clll}
\hline $\begin{array}{c}\text { Nama } \\
\text { Aktor }\end{array}$ & \multicolumn{1}{c}{ Tugas } & \multicolumn{1}{c}{ Deskripsi } \\
\hline Admin & 1. & Login & Aktor yang bertugas mengelola agent \\
& 2. & Halaman utama chatbot \\
& 3. & Input Pertanyaan & $\begin{array}{l}\text { chatbot, data pertanyaan dari user, dan data } \\
\text { jawaban pada agent chatbot. }\end{array}$ \\
4. & Input Jawaban & \\
Chatbot & 1. & $\begin{array}{l}\text { Mengelola data sesuai arahan } \\
\text { admin }\end{array}$ & $\begin{array}{l}\text { Aktor yang merupakan agent chatbot, } \\
\text { bertugas mengelola informasi yang diberikan } \\
\text { sesuai arahan admin. } \\
\text { Aktor yang bertanya dan melakukan }\end{array}$ \\
& 2. & $\begin{array}{l}\text { Menjawab pertanyaan user } \\
\text { pengajuan pertanyaan melalui chatbot. }\end{array}$ \\
\hline
\end{tabular}

Untuk merancang pengetahuan pada Chatbot di bentuk pola pertanyaan berdasarkan topik pembahasan. Pada tabel 2. Merupakan contoh salah satu topik dalam pola pengetahuan chatbot website Sistem Informasi.

Tabel 2. Pola Pertanyaan SIBot

\begin{tabular}{lll}
\hline No. & Topik Pertanyaan & \multicolumn{2}{l}{ Pola Pertanyaan } \\
\hline 1 & SMART SITA & a. Apa itu SMART SITA \\
\hline
\end{tabular}




\begin{tabular}{lll}
\hline No. Topik Pertanyaan & Pola Pertanyaan \\
\hline & b. & Fungsi SMARTSITA \\
& c. & Link SMART SITA \\
\hline
\end{tabular}

Selanjutnya merancang tanggapan untuk setiap topik pengetahuan pada chatbot. Pada tabel 3, merupakan bentuk tanggapan pada salah satu contoh topik dalam pengetahuan chatbot website sistem informasi.

Tabel 3. Tanggapan SIBot

\begin{tabular}{lllll}
\hline No. & Topik Pertanyaan & Tanggapan & & \\
\hline 1 & SMART SITA & $\begin{array}{l}\text { SMART SITA merupakan website } \\
\text { berfungsi sebagai tempat .... }\end{array}$ & &
\end{tabular}

Berikut link SMART SITA :

Setelah merancang pola pertanyaan dan tanggapan untuk setiap topik, dilanjutkan untuk mengimplementasikan pengetahuan chatbot kedalam bentuk database Mysqli. Pada tabel 4, merupakan pengetahuan chatbot dalam bentuk database mysqli.

Tabel 4. Tanggapan SIBot

\begin{tabular}{llllll}
\hline id & Question & Answer & & \\
\hline 1 & SMART SITA | Apa itu & SMART SITA merupakan website & yang \\
& SMART SITA | Fungsi & berfungsi sebagai tempat .... & & \\
& SMART SITA | Link & & & \\
& SMART SITA & Berikut link SMART SITA : &
\end{tabular}

Pada tabel 4. terdapat tanda "| "yang berfungsi sebagai pemisah untuk setiap pola pertanyaan. Dalam database mysqli, untuk kolom "question" diberikan type data "VARCHAR" sehingga setiap pertanyaan dalam topik akan direspon pada kolom answer dengan topik yang sama.

\subsection{Implementasi Sistem}

Penerapan chatbot pada website Sistem Informasi memiliki skenario awal dengan memberikan masukan text sapaan serta pemberian daftar isi mengenai informasi atau pengunguman penting yang tertera pada website Sistem Informasi. Kemudian pengguna melanjutkan untuk memasukkan text kata kunci. Apabila kata kunci yang di masukkan ada dalam database pengetahuan chatbot, maka pengguna akan segera mendapatkan tanggapan. Namun, jika kata kunci yang di masukkan belum tersedia dalam database pengetahuan pada chatbot, pengguna akan mendapatkan tanggapan maaf dan pemberian kontak admin Sistem Informasi.

Proses ini sangatlah penting agar admin dapat segera menjawab pertanyaan user yang tidak terjawab serta menambah pengetahuan chatbot mengenai topik pertanyaan tersebut ke dalam database chatbot. Dalam hal ini, maka implemetasi chatbot dibagi menjadi dua antarmuka, yaitu pada halaman administrator. Dan yang kedua pada halaman user.

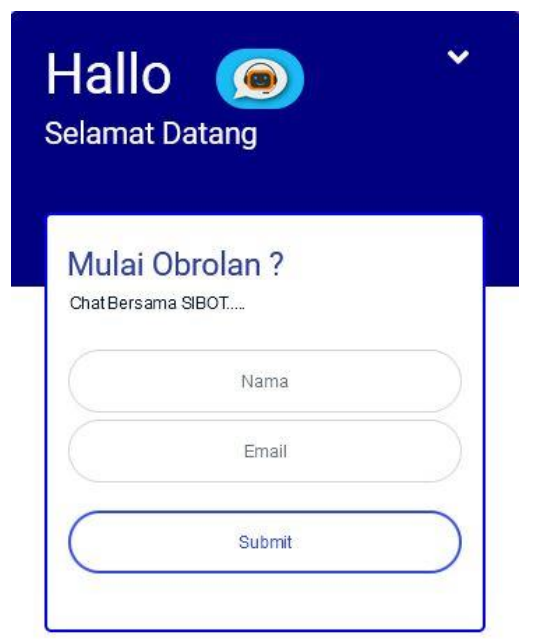

Gambar 5. Tampilan Chatbot User 
ISSN 2614-5278 (media cetak), ISSN 2548-8368 (media online)

Available Online at https://ejurnal.stmik-budidarma.ac.id/index.php/mib DOI 10.30865/mib.v5i1.2623

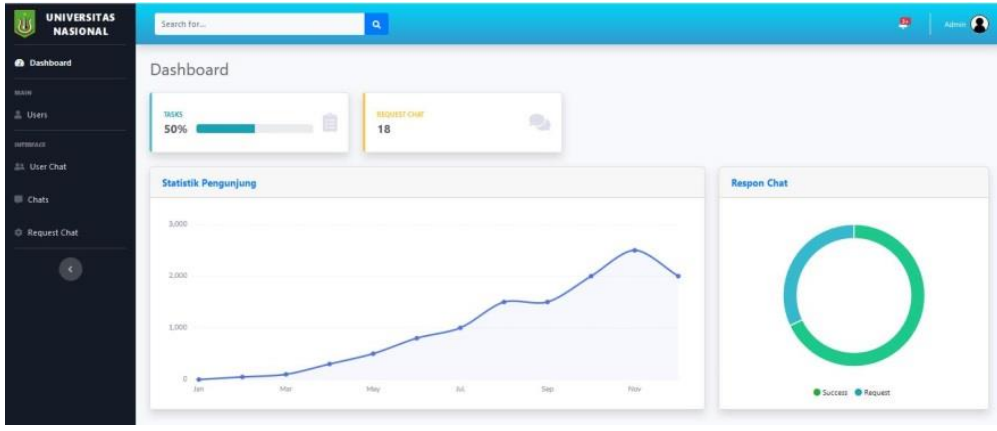

Gambar 6. Tampilan Halaman Admin Chatbot

\subsection{Pengujian Sistem}

Pengujian chatbot ini dilakukan pada antarmuka user, dengan memberikan pertanyaan pada chatbot. Misalnya user dapat memberikan pertanyaan "apa itu smart sita?". Kemudian penguji dapat melihat seberapa akurat jawaban chatbot dan bagaimana efektivitas atau berapa lamanya waktu yang diperlukan chatbot untuk mengolah informasi yang ditangkapya.

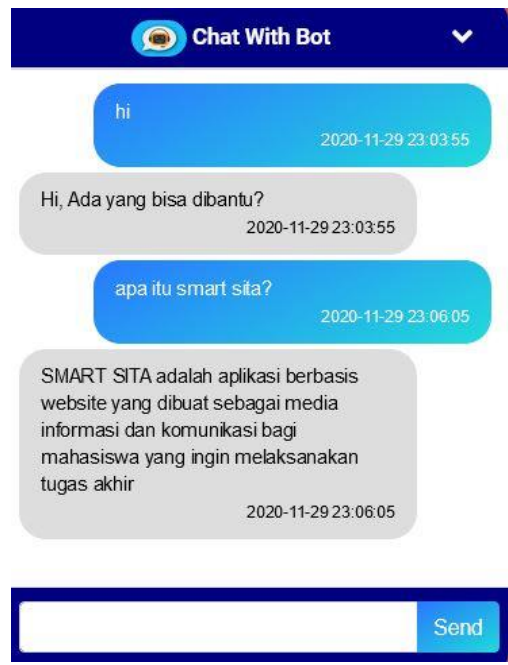

Gambar 7. Pengujian Chatbot

\section{KESIMPULAN}

Berdasarkan hasil analisis, design, implementasi dan pengujian yang dilakukan pada fitur chatbot ini, dapat diambil kesimpulan bahwa, chatbot yang diterapkan di website program studi sistem informasi dapat menjawab pertanyaan dengan baik, sehingga dapat membantu user untuk memperoleh jawaban terkait kebutuhan informasi akademik. Selain itu, tidak terdapat kesenggangan waktu yang terlalu lama untuk user mendapatkan jawaban dari chatbot, dengan ini menjadikan chatbot yang diterapkan dapat bekerja dengan cepat dan akurat. Penerapan chatbot ini juga tetuunya dapat meminimalisir tugas admin sebagai customer service sehingga tidak perlu menjawab pertanyaan yang kerap berulang kali ditanyakan oleh user.

\section{REFERENCES}

[1] E. L. Amalia and D. W. Wibowo, "Rancang Bangun Chatbot Untuk Meningkatkan Performa Bisnis," J. Ilm. Teknol. Inf. Asia, vol. 13, no. 2, p. 137, 2019, doi: 10.32815/jitika.v13i2.410.

[2] S. Nurhayati and M. A. H, "Pembangunan Aplikasi Chatbot Midwify sebagai Media Pendukung Pembelajaran Ilmu Kebidanan Berbasis Android di Stikes Bhakti Kencana Bandung," Komputika J. Sist. Komput., vol. 8, no. 1, pp. 45-52, 2019, doi: 10.34010/komputika.v8i1.1630.

[3] Ananda Dwi, F. Imamah, Y. M. Andre, and Ardiansyah, "Aplikasi Chatbot (Milki Bot) Yang Terintegrasi Dengan Web CMS Untuk Customer Service Pada UKM MINSU,” J. Cendikia, vol. XVI, pp. 100-106, 2018.

[4] M. H. Wijaya, M. Sarosa, and H. Tolle, "Rancang Bangun Chatbot Pembelajaran Java pada Google Classroom dan Facebook Messenger," J. Teknol. Inf. dan Ilmu Komput., vol. 5, no. 3, p. 287, 2018, doi: 10.25126/jtiik.201853837.

[5] B. Rusmarasy, B. Priyambadha, and F. Pradana, "Pengembangan Chat Bot pada CoMa untuk Memberikan Motivasi Kepada Pengguna Menggunakan AIML," J. Pengemb. Teknol. Inf. dan Ilmu Komput., vol. 3, no. 5, pp. 4484-4490, 2019.

[6] E. Bahartyan and N. Bahtiar, "Web E-Commerce," vol. 5, pp. 34-43, 2014.

[7] M. Astuti, Rani Natadian; Fatchan, "Perancangan Aplikasi Teknologi Chatbot Untuk INDUSTRI KOMERSIAL 4.0," Pros. Semin. Nas. Teknol. dan Sains, vol. 1, no. September, pp. 339-348, 2019, [Online]. Available: 
JURNAL MEDIA INFORMATIKA BUDIDARMA

Volume 5, Nomor 1, Januari 2021, Page 273-279

ISSN 2614-5278 (media cetak), ISSN 2548-8368 (media online)

Available Online at https://ejurnal.stmik-budidarma.ac.id/index.php/mib

DOI 10.30865/mib.v5i1.2623

http://journal.unusida.ac.id/index.php/SNTS/article/viewFile/402/311.

[8] A. El Hayat Soumiya and M. Bahaj, "Converting UML class diagrams into temporal object relational database," Int. J. Electr. Comput. Eng., vol. 7, no. 5, pp. 2823-2832, 2017, doi: 10.11591/ijece.v7i5.pp2823-2832.

[9] D. Christianto, E. Siswanto, and R. Chaniago, "Penggunaan Named Entity Recognition dan Artificial Intelligence Markup Language untuk Penerapan Chatbot Berbasis Teks," J. Telemat., vol. 10, no. 2, p. 8, 2016.

[10] D. R. Lakshmi and S. S. Mallika, "A review on web application testing and its current research directions," Int. J. Electr. Comput. Eng., vol. 7, no. 4, pp. 2132-2141, 2017, doi: 10.11591/ijece.v7i4.pp2132-2141.

[11] D. K. Kim, "Development of mobile cloud applications using UML," Int. J. Electr. Comput. Eng., vol. 8, no. 1, pp. 596-604, 2018, doi: 10.11591/ijece.v8i1.pp596-604.

[12] A. A. Akhsan and F. Faizah, "Analisis dan Perancangan Interaksi Chatbot Reminder dengan User-Centered Design," J. Sist. Inf., vol 13, no. 2, p. 78, 2017, doi: 10.21609/jsi.v13i2.555.

[13] I. N. S. Paliwahet, I. M. Sukarsa, and I. K. Gede Darma Putra, "Pencarian Informasi Wisata Daerah Bali Menggunakan Teknologi Chatbot," Lontar Komput. J. Ilm. Teknol. Inf., vol. 8, no. 3, p. 144, 2017, doi: 10.24843/lkjiti.2017.v08.i03.p01.

[14] K. Benmoussa, M. Laaziri, S. Khoulji, K. M. Larbi, and A. El Yamami, "A new model for the selection of web development frameworks: application to PHP frameworks," Int. J. Electr. Comput. Eng., vol. 9, no. 1, p. 695, 2019, doi: 10.11591/ijece.v9i1.pp695703.

[15] K. Abdelazim, R. Moawad, and E. Elfakharany, "A Framework for Requirements Prioritization Process in Agile Software Development," J. Phys. Conf. Ser., vol. 1454, no. 1, 2020, doi: 10.1088/1742-6596/1454/1/012001.

[16] S. Nidhra, "Black Box and White Box Testing Techniques - A Literature Review," Int. J. Embed. Syst. Appl., vol. 2, no. 2, pp. 29-50, 2012, doi: 10.5121/ijesa.2012.2204.

[17] R. r. Benedictus, H. F. Wowor, and A. Sambul, "Rancang Bangun Chatbot Helpdesk untuk Sistem Informasi Terpadu Universitas Sam Ratulangi," J. Tek. Inform., vol. 11, no. 1, 2017, doi: 10.35793/jti.11.1.2017.16557. 